\title{
HUNGARY AND CHINA: CHALLENGES AND RISKS FACING THE TAX AND CUSTOMS AUTHORITY
}

The objective of the study is to provide an overview of the current state of the Chinese-Hungarian trade policy, particularly taking into account the fact that Hungary is a member-state of the European Union, moreover its revenue authority will presumably face certain professional as well as quantitative challenges. The research study summarizes the findings available within the domestic and international academic literature, with special concern on the issues of Belt and Road Initiative (BRI) and its specific aims involving Hungary as one of the main railroad gateways of the container cargo-shipments. Besides, we shall also analyze the data of the Hungarian Central Statistical Office, furthermore the figures of the National Tax and Customs Administration.

The aim of the "Eastern opening" of Hungary is to find new raw material resources and markets for the Hungarian corporations, since the economies to the west of Hungary are featured by high wages and shipment costs. It is no question that the focal point of the global economy has shifted towards the East in the 21 st century, and Asia has become the continent with the biggest buyer's market in the world. Based on this idea it is important to mention that the Eastern opening does not focus exclusively on the People's Republic of China, but it also involves all the major regions (Majoros, 2008: 11), from the Caucasus region through the Balkans to the Arab world.

The gross volume of the bilateral trade between China and Hungary rested on HUF 382 billion in 2001 based on the figures of Hungarian Central Statistical Office, and HUF 1284 billion in 2010, while after a 4-year long drop it soared to HUF 1700 billion by 2018 (data without Hong Kong and Taiwan).

The rising figures also imply the transformation of the task system of the national revenue authority, furthermore with the necessity of tackling the growing number of new type of professional procedures related to human resources and customs administration. It can be observed that the national revenue authority does whatever it can within its framework to comply with the European expectations, among other issues by decreasing the customs procedures length, by implementing the so-called fair price policy, centralizing the customs locations, altogether contributing to the implementation of unitary and swift customs procedures. For the purpose of recognizing and tackling with the risks, it also shares tight cooperation protocols with the World Customs Organization as well as with the institutions of the European Union, for instance with the $O L A F$ and the Europol.

Key words: international trade, Eastern opening, New Silk road, revenue authority, solutions, customs. JEL Classification: F13, F15, F18, F63, K39.

Andrea SZABÓ,

Head of Customs and Finance Guard Department

of the Faculty of Law Enforcement University of Public Service,

Associate Professor

szabo.andrea@uni-nke.hu

orcid.org/0000-0002-8224-4089

\section{Dávid TAKÁCS,}

Excise Officer, First Lieutenant,

National Tax and Customs

Administration of Hungary,

Central Hungarian Crime Directorate,

Postgraduate Student

takacs.david_1@nav.gov.hu

\section{Introduction}

The objective of the study is to provide an overview of the current state of the Chinese-Hungarian trade policy, particularly taking into account the fact that Hungary is a member-state of the European Union, moreover its revenue authority will presumably face certain professional as well as quantitative challenges.

\section{Trade relations between China and Hungary}

The People's Republic of China, with its population of 1.3 billion people currently is the second largest economy in the world, behind the United States. The country produced $15 \%$ of global GDP back in 2015 (KSH, 2014: 1), which has been rising ever since then mostly triggered by intensive export activities. For this reason Beijing tends to prevent any scenarios which would result in a fallback in export. Parallel with its rising importance in global trade, and besides its domestic reforms this high-ranking prestigious position may be accounted for through the improvement of Chinese technological, 
Kristóf Péter BAKAI,

Director General for Customs

National Tax and Customs

Administration,

PhD Candidate

bakai.kristof@nav.gov.hu

orcid.org/0000-0002-1809-5533 military capacities, increasing regional and global influence and joining international institutions.

The global financial crisis of 2008 demonstrated the significant and rising economic importance of China, since from among its competitor adversaries China proved to be the fastest country to get through and raise from the crisis. The US announced the "Pivot to Asia" program in 2011 (Chen, 2013) aiming to contain and counterbalance the ambitious expansion of China. China responded with the "One Belt, One Road" program (P. Szabó, 2020: 23; EPSC, 2016), which undoubtedly has demanded amicable and peaceful trade environment and prosperous international relations (Kocsis et al., 2017: 14; Kína Online, 2017).

Hungarian Central Statistical Office (hereinafter - KSH) issued its last analysis exclusively focusing on the relations of the two countries in 2014. From this document reveals that in terms of import China is one of the most significant trade partners of Hungary. In the period of 2003 and 2008 import from China rose with 24\% in average per annum with a trade value of HUF 1,200-1,300 billion between 2010 and 2012 (Szunomár, 2015: 64). As for the structure of commodities, more than half of import trade consisted of telecommunication, voice record and player devices (P. Szabó, 2011: 49-50). Besides these, the amount of food industrial products, raw materials and fuels constitute a negligible proportion. Interestingly, contrary to the common belief the ratio of imported textile and clothing products from China made up only $0.6 \%(\mathrm{KSH}, 2014: 3)$.

It is noticeable, that Hungary could significantly expand its export trade to China even in the global crisis year of 2009. This implied a $6.5 \%$ rise in export compared to the figures of the previous year, while the Hungarian import from China fell with $13 \%$ in that year. In 2012 the Hungarian export grew with 7\%, while the import trade fell with $11 \%$. As for the Hungarian export to China, it significantly lags behind the import trade value. In 2012, for instance we sold products in value of USD 407 billion, which made up merely the $1.8 \%$ of total Hungarian export trade (Szunomár, 2015: 64).

According to the data of KSH Hungary, in 2018-2019 from the top 10 most important trade partners of Hungary 8 countries were from the European Union, besides China and the Russian Federation. In 2018 China occupied the $4^{\text {th }}$ position, while by 2019 it came up to the second position with HUF 2,071 billion gross value imported goods (KSH, 2020: 23).

Among Hungarian products with the best chances to break into the Chinese market we can find the raw and prepared meat products, baby food and sweets, candies. There is also room for expansion in the field of quality mineral water since there is a spectacular demand for high quality foreign products in China. There is also a significant growth in the export of quality wine compared to the previous years, which is also partly due to the more active participation of Hungarian wineries in international wine fairs. The biggest demand is shown for premium quality wine category, competing with the wine products from Chile, Spain, Italy, and South Africa.

In order that our export trade to China may increase and expand, there are certain necessary actions that must be taken in various fields. The Hungarian corporations lack the funds to conduct market surveys and maintain permanent representative offices in China. 
The Hungarian corporations have to prepare to various factors before entering the Chinese market, for example, being aware of copycats of their branded products, different consumer habits from Europe and weaker remuneration willingness.

The data of PAGEO Geopolitical Research Institute show that the gross value of Chinese foreign direct investment (FDI) in Hungary reached USD 2.1 billion in the 17-year long period between 2001 and 2017 (Róma, 2018). In comparison, the value of FDI in the whole region accounted for USD 3.8 billion, with Poland coming second with USD 1 billion investment rate (Róma, 2018). We can state that the great bulk, almost two-third of the Chinese investments arrived into Hungary within this time-frame.

At the China-Central East European (CEE) countries summit held in Bucharest in November 2013, there was a decision in principle made on the renovation of the Belgrade-Budapest railroad with the participation of the Hungarian and Serb prime ministers. The total cost of the project was then estimated to be set on HUF 750 billion, a great bulk of it would be covered from a Chinese loan to Hungary (URL1). In December 2014, China and the CEE countries signed the so-called Belgrade Directives, which among other things contained guidelines for easing the customs procedures (Belgrade Guidelines, 2015). In the fall of 2017 Budapest hosted the "16+1 Cooperation"1 (Eszterhai, 2017; URL2; Goreczky, 2017; Rácz, 2020: 151) summit, where the heads of delegation of the two countries signed more than 10 agreements (URL3). In 2019 the Hungarian minister of finances pursued discussions in Beijing about the planned railroad reconstruction. According to the feasibility plan, the project will be elaborated by a consortium comprising Hungarian and Chinese companies with a deadline date of 2023 (URL4), though currently the project completion deadline has been updated and shifted to 2025 (URL5).

Thanks to the loans and tight cooperation a pneu-press-equipment manufacture subsidiary of the Himile corporation was established in Székesfehérvár, the Lenovo company mostly producing IT devices announced a factory expansion plan, while at Szolnok the citric-acid factory was established and in Komárom the project of the first electric-bus factory plant in Europe was elaborated. The Wanhua Industrial Group acquired the Hungarian BorsodChem Closely Held Corp., establishing a chemical industrial plant, which has turned into the third largest isocyanides-producer in the world. The Hungarian subsidiary of the Huawei Inc. also carried out a serious expansion and development project, thus the European Huawei Logistic Center as well as the Huawei Europe Supply Center can operate in Biatorbágy (Hszü, 2019: 60). The latest investment of the company consists in the establishment of the research and development facility center in Budapest which focuses on the examination of artificial intelligence, signal transmission and procession technologies and research and development of big volume network and switch-systems (MTI, 2020).

Prior to the new Silk Road rail-link between China and Europe the preferred means of trade were either by maritime shipments (slow but low-fare) or air-cargo (expensive but fast). However, the new Eurasian rail-link enables the shipments to arrive at their destinations within two weeks (Engelberth Sági, 2017: 89) for half the price of the air-cargo costs, which altogether would mean quick and low cost transportation of goods. By establishing the transcontinental railroad connections China aims to benefit from transporting goods by train, which previously had been predominantly carried by sea or by air.

Europe and Asia are linked by diverse rail-freight corridors (URL6), from which two lines have direct access to Hungary, too:

1. Záhony (HU) - Chop (UA): RFC 6 line 7,000 km long with countries accessed: Spain, France, Italy, Slovenia, Hungary, Croatia.

2. Svilengrad (BG) - Kapikule (TR): RFC 7 line, 7,700 km long, connected countries: Czech Republic, Austria, Hungary, Romania, Greece, Bulgaria, Slovakia.

This latter line is to be involved into the railroad reconstruction project between Belgrade - Budapest, and since Greece also develops its own railroad network the commodities arriving from China into the Pireus or Thessaloniki ports will also be forwarded through this rail line towards South-East or Central Europe. At present the biggest problem seems to stem from the different track-gauge of the lines and from the resulting freight reload.

\section{Risks - threats - dangers}

Hungary with the European Union accession also joined the common customs union, so the Hungarian tax and customs authorities must comply with full responsibility with the regulations and protection of the financial interests of the European Union. In compliance with this state of affairs, all the risks must

It has been extended to Greece, too into 17+1 cooperation since 2019. 
be tackled with proper care and the authorities must introduce certain measures that they simply cannot neglect. In case of risk elements, the time span of customs procedures may be affected by various factors, for example, the quality of the initial consignment report, the necessity of goods-sampling, freight control, abundance of risky shipments, furthermore the human resource capacities of the assigned customs control directorate (Csaba, 2012a). IT support, the development of which began before EU accession, is also important. The Interoperability Project (IOP), established at the National Headquarter of the Customs and Finance Guard (NHCFG) in early 2002, was responsible for the development and implementation of customs information systems, the existence and operation of which was an expectation of the EU. This working group also performed the testing and implementation of the systems, the preparation of the users, the preparation of the changes in the legal sources necessitated by the IT developments, and all other related tasks (Suba, 2015). It can be also stated in connection with certain products coming from China, e. g. shoes and clothing products, that they share multiple risk factors, such as under-invoicing, copyright and industrial brand protection problems, deficiencies related to quality regulations and standards etc., which may emerge simultaneously, thus it may deserve increased concern and care.

Stemming from the aforementioned freight transport irregularities the expected eastbound empty containers would pose not only fiscal problems as well. The customs authorities deal differently with inbound and outbound destination freight traffic. Export transport is promoted even despite security risks by the states, while their own security measures are primarily implemented with the imported shipments, so security risks for outsiders is rarely taken into consideration (Barton, 2007). It would be worth thinking over and developing further the elastic border control ideas of Barton, regarding the options for improving the security measures related to long distance empty container transportation in both directions. In compliance with the framework of WCO SAFE, the risk-management and reduction measures may as well be applied at the unit-based container loading processes or at the multimodal relations ${ }^{2}$ through monitoring and controlling the containers and forwarding and sharing the risk assessments and control results digitally with all the customs agencies along the long supply chain. Promoting the participation of freight transport companies in the AEO program of the European Union would also facilitate security and transparency concerning the visibility of the low-risk shipments within the intercontinental freight transport systems. For decreasing the specific reverse logistical security risks posed by the empty containers' transport, locking these units and digitally tracking and sharing their details with the risk assessment authorities may be a proper solution (Csaba, 2012b; Csaba, 2013). These issues, though raise the necessity of participation in the customs administrations' cooperation framework of all the countries along the supply chain, not only that of China, the European Union members states involved or of the European Commission.

Along the recent years there has been such a significant growth in rail cargo transport and volume of shipments between Asia and the European Union, Hungary included, which must be considered serious security risk since it has created new opportunities not only for legal freight transport but also for illegal trade activities, too. The features of this phenomenon must be continuously and repeatedly analyzed, examined and the research findings must be inserted into the risk assessment systems. We can initially presume that through the opening of new routes and channels of freight transport the multiplicity of shipments may also involve the emergence of new segments and aspects of criminal activities.

Significant amount of the illegal tobacco products targeting the European markets are produced within the territory of People's Republic of China, furthermore this country can also be regarded as the main source of fake cigarette produces, too. More than 200 billion fake cigarette threads are produced in China annually, partly ending up in Europe. Majority of filters used in illegal cigarette manufactories in Europe also originate from China (URL7).

Cigarettes proves to be an attractive object of smugglers: it has relatively small mass, easy to transport, large buyers' markets and it provides an extremely high revenue for the criminal organizations involved. In contrast the criminals involved in smuggling must face with quite low reconnaissance risks and the sanctions are also rather mild. Cigarette smuggling proves to be one of the major generator of corruption and bribery along the Eastern frontiers of the Union (Europol, 2017a).

All the same, one of the major social challenges of the new millennium constitutes the quick spread of psycho-active materials, designer drugs, which also share serious Chinese affiliations, since significant amount of these drugs are produced there (Erdös, 2021: 8). Ever since the beginning of the 2000's in Europe as well as in Hungary the presence of this kind of narcotics has been prevailing, for which many

Here referrimg especially to: road-railroad and railroad, road and sea connections. 
correlating factors may be blamed, such as partly the low price set by the producers, easy access and the advantages of online trade used as a global drug-market (Erdős, 2018: 87). Besides the criminal aspects of international trade, it is a commonly known revelation that the expanding Chinese economic and political affection also poses significant strategic challenges for the Westerns world, especially for the leading global power, the United States (Csutak, 2019; Csutak, 2020).

Along the external frontier line of the European Union there are either few, reduced or no border control for railroad crossing. The places where border control procedures are applied, these are carried out with X-ray equipment, sniffing dogs, video endoscopes, detectors, mirrors. On the spot X-ray scanner exists only at Malaszewicze and at Záhony, since all the other railroad border crossing stations do not possess such an equipment (Kovács, 2016; Horváth, Kovács, 2014).

The physical control of the freight carriages proves to be clumsy and complicated, thus for the efficient, swift and undamaged check and control of the rail cargo the application of X-ray devices is of outstanding importance. Another very important factor is the professionalism of the controllers, the usage of the technical appliances, since without these factors the rail cargo control can easily become fragile and vulnerable. Moreover, experience also shows that the authorities may not or hardly can access the rail freight related data: registry number of trains, number of carriages, timetable, number of containers, or details of the carried goods. Exclusively the details of the dangerous materials must be reported beforehand.

\section{Duties of the Hungarian revenue authority - solutions}

The expectation of the European Union from the European customs administrations - for ensuring the revenues from customs duties - does not restrict and imply the supervision of the international trade solely or taking action against the illegal and unfair business conducts, but it is also partly their duty and responsibility to protect and safeguard all those living and working within the boundaries of the Union. Accordingly, the National Tax and Customs Administration of Hungary (hereinafter - NTCA) can perform all the necessary customs procedures available (Suba, Szendi, 2018).

Merging two predecessor institutions of NTCA - the national Customs and Finance Guard and the Hungarian Tax and Financial Control Administration - the legislator intended to elevate into a new, higher and more efficient dimension, which would desirably result in collecting the state budgetary income with much bigger efficiency (Magasvári, 2018: 35). The $13 \S$ paragraph of the Hungarian Law on NTCA ${ }^{3}$ meticulously describes the duties and responsibilities of NTCA - adjusting to the competences and tasks of the predecessor institutions - which can be categorized as tax management, customs administration, revenue administration, crime prevention and prosecution, moreover law enforcement and justice administration (Szabó, 2016: 202).

As a result of the organizational integration (Magasvári, 2015; Magasvári, 2018) it can be affirmed that the tax, customs, crime investigation and law enforcement type of reactions and solutions belong to the task force of one state authority in Hungary since 2011, particularly related to the "quantitative and qualitative" challenges posed by the European and especially Hungarian import of Chinese commodities, as it is also analyzed in this paper.

The Chinese "One Road One Belt Initiative" (recently renamed to Belt and Road Initiative, BRI) (Connections, 2013; EPSC, 2016; Kocsis et al., 2017; Kína Online, 2017) resonates well with the Hungarian "Eastern opening" economic policy program, also launched a few years ago. The National Tax and Customs Administration takes an active role in all the operational areas, like the $16+1$ cooperation initiative, or the Piraeus railroad-related $4+1$ customs cooperation formation. NTCA tend to do its best to fulfill its tasks and duties in compliance with the valid legislation so as to perform swiftly and smoothly the customs administration of the Chinese commodities (NAV, 2020a: 49).

The NTCA has also made efforts for improving and facilitating the flow of information between the Chines partners and the customs authorities, furthermore to extend the information share with the Chinese partners concerning the European customs and tax legislative framework. For this reason a Chinese version website of NTCA has also been developed, and with the contribution of some NTCA experts useful publications have been compiled for informing the foreign trade partners and customers (P. Szabó, 2011: 49-50).

Provided that we examine the figures on the imported Chinese goods, we can realize that the statistical value inclines between 24-30\% compared to the gross import value, while the customs rate imposed on the Chinese products is around $44-58 \%$ of the total imported volume and it also produces a steady growth.

CXXII. Law (2010) on establishing the Hungarian National Tax and Customs Administration. 


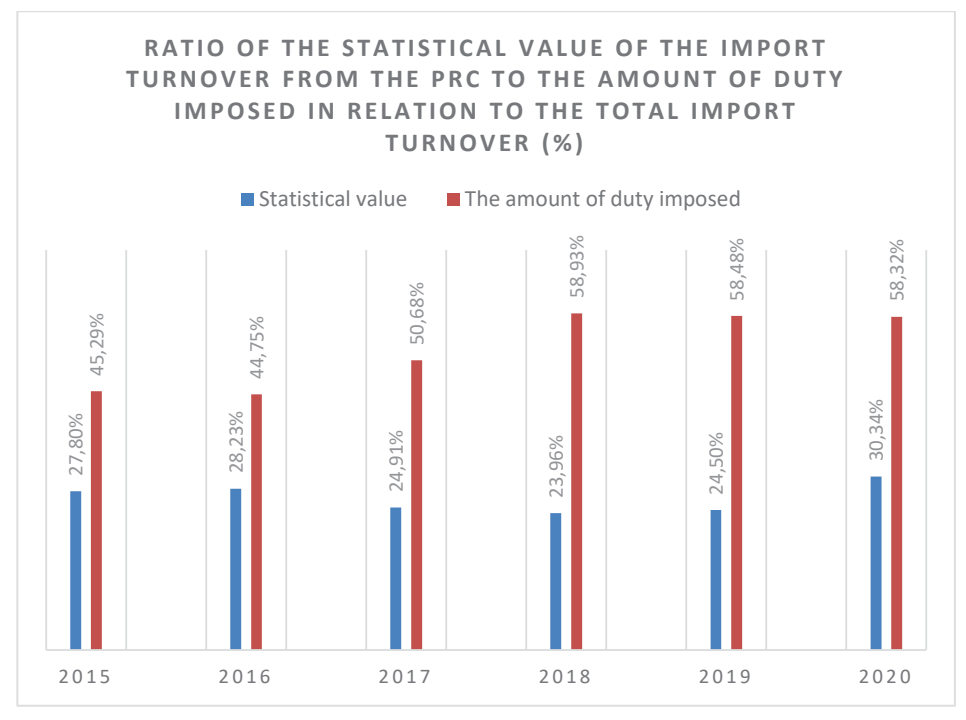

Source: NTCA

NTCA performs its activities professionally, legally and in a customer-oriented manner, laying great emphasis on promptness. Provided all the necessary documents are available for the authority and all the legal conditions are also valid to perform the customs control procedures, the cargo may be delivered on within 23 minutes average control time. In case of emerging risk, this process may take even more days. Most frequent risks factors are the low customs value (undervaluation), incorrect customs tariff numbers, breaching product safety regulations, compromised brand or copyright protection (fraud) (Bakai, 2016).

The customer may require customs control anywhere in the territory of the EU, according to this regulation almost all the container shipments coming from China arrive at the NTCA South Budapest Tax and Customs Directorate for customs procedures. The directorate deals with so-called target freight trains coming from major European ports, like Hamburg, Koper, Piraeus in several logistical centers (NAV, 2020b: 10). As we indicated before, more and more cargo arrive on direct railroad links also into these logistical centers.

The chart below shows on two diagrams the change of Chinese product importers' numbers as well as the number of customs procedures in the three major directorates in Budapest. Based on these figures, the Airport Customs Directorate shows extremely high numbers - thanks to its special characteristics and venue (international airport, post office and external border station of the EU) (NTCA ACD: NTCA Airport Customs Directorate; NTCA SBTCD: NTCA South Budapest Tax and Customs Directorate; NTCA PCTCD: NTCA Pest County Tax and Customs Directorate).

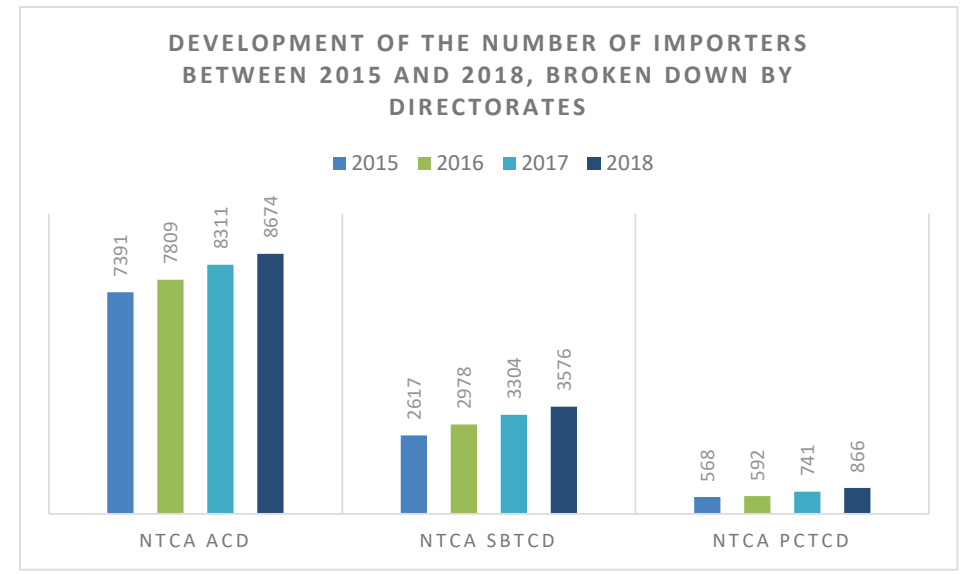

Source: NTCA 


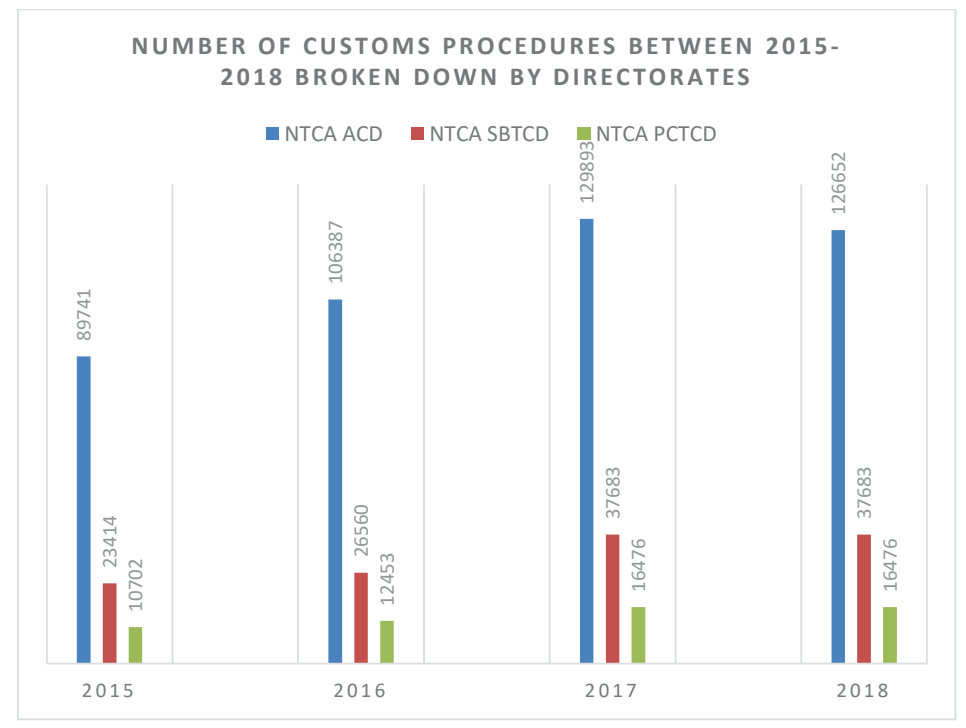

\section{Source: NTCA}

In the European Union as well as in Hungary it has been a recurring problem for several years the issue of under-billing, which cause significant budgetary losses both for the EU and the member states. To prevent and avoid this phenomenon the European Commission has imposed a so-called "fair price" threshold in the case of certain sensitive products - shoes and textile items - coming from Asian countries, and demands increased care and supervision in this case from the customs authorities (Andó, 2019).

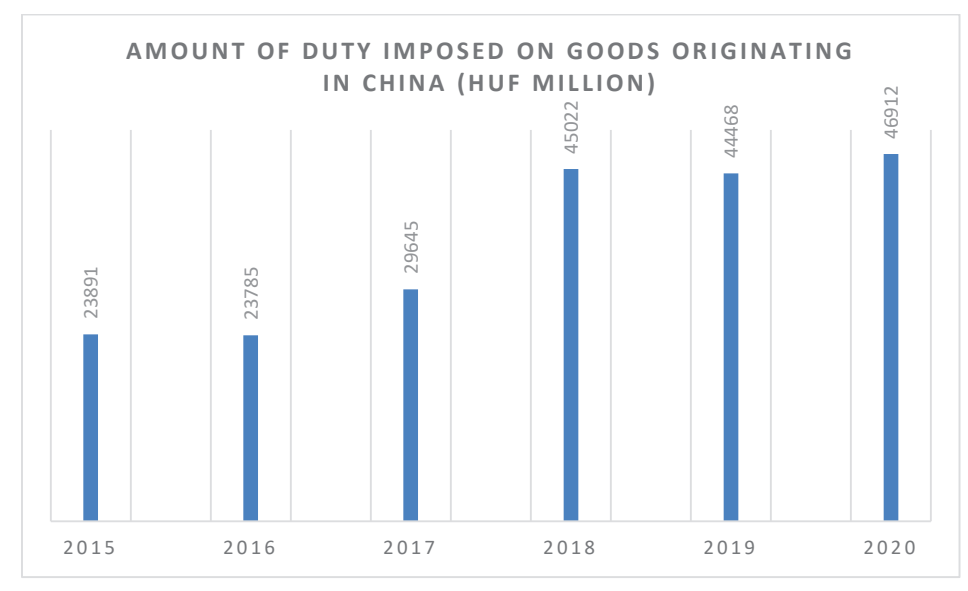

\section{Source: NTCA}

From the diagram it reveals that the amount of customs tariff paid after the Chinese products shows growth since 2018, due to the implementation of the aforementioned fair pricing and the focused control carried out by the customs authorities. As it can also be highlighted from the previous chart, the COVID-19 pandemic did not have a significant impact on the volume of trade.

The European Union not only expects the supervision of international trade from the customs authorities so as to ensure the revenues from the customs tariffs - and proper counteraction against any illegal and unfair business conduct but these authorities are also in charge of the safety and protection of all the subjects residing or sharing business facilities on the territory of the Union. According to this prerequisite, NTCA as customs organ may and can perform all the necessary customs procedures under its authority (Suba, Szendi, 2018: 166).

As of July 1, 2021 significant change is due with the abolition of the VAT-free category for any product under 22 Euro value. This primarily affects the online market sector. From one hand, the trans-border trade resulted in loss of revenues for the European Union, from the other hand the VATfree closure also provided illegitimate business advantage for third party traders. The Hungarian Postal 
Service is preparing with automatic customs control for the ensuing change in legislation, while the EU tends to ease the administrative burdens with launching a new and simpler type of freight-report document (NAV, 2021).

The Council of the European Union so as to perform its duties is assisted by the Customs Cooperation Work Panel (CCWP), which deals with the operational level cooperation among the national customs authorities to foster executive competences. This workgroup defines the strategic and tactical objectives of the common customs operations. It tries to make success in performing cargo seizures, identifying new threats and eliminating criminal groups (URL8). The workgroup maintains tight cooperation with Europol, the European anti-fraud office (OLAF) and European border and coast guard agency (Frontex).

The Europol databases as well as the analytic workfiles and projects, target groups enable the organization to show prompt and accurate response, furthermore the national liaison officers' networks and the successful criminal prosecution cooperation schemes provide helping tools for spotting and investigating various illegal activities, rolling up organized crime networks and taking the perpetrators into court (Szabó, 2012). Europol has a strategic cooperation agreement to withhold and push back crossborder organized crime signed with the People's Republic of China in April 2017. The agreement, though does not involve and permit the exchange of personal data (Europol, 2017b).

One of the outstanding operations heralding the cooperation between OLAF and the customs authorities of nation states, proved to be the customs operation with the codename SNAKE from 2016, which aimed to restrain and push back the under-billed textile and shoe products imported from China (Bakai, 2016). The operation partnered and got involved with the Chinese Anti-Smuggling Bureau, too. The operation resulted in hindering the European budget loss in the value of 80 million Euro (URL9).

\section{Conclusions}

Chinese trade connections prove to be of great importance in many states of the region, and according to the statistics China has become the largest trade partner of the EU. It is a non-concealed aim of the EU to deepen and expand the current ties and connections and to make further investment projects, though strictly within the frameworks of commonly approved norms and standards.

There is no question about the importance of the Chinese connections for Hungary, also underlined by the statistical figures, since China has become one of the most important trade partners of Hungary next to the EU. Experiences so far also demonstrate that Hungary proves to be a similarly important partner for China, taken the advantageous geographic position of our country, being situated along the external frontier line of the EU as well as in the middle of the Central and East European region. We can assume that the sectors with the brightest perspectives from Hungarian standpoint would be tourism, water management, environmental protection, agriculture, healthcare industry, education and technologyfocused know-how industry (Mátyás, 2016).

The priorities may change from both parties' standpoints and directions, thus taken these factors into account may be important in the future, too, especially that our country does not share autonomous decisionmaking capacity in a series of crucial, trade-related matters. The latter is not merely a disadvantage by all means, only demands more careful considerations in cooperation frameworks.

The customs procedures of container shipments' at Záhony border-crossing station and along the Belgrade-Budapest railroad pose quite a significant challenge for the Hungarian customs authority, similarly to the effects of legislative changes coming into effect as of July 1,2021 concerning the abolition of VAT-free status of all consignments under 22 Euro value. Regarding the COVID-19 pandemic effects we can conclude that it did not alter significantly the volume of trade, rather reorganized it, particularly concerning various swaths of cargo shipments.

\section{References:}

1. Andó, G. (2019). A kínai áruforgalom magyarországi vámkezelésének felgyorsítása [Accelerating the customs procedures of the Chinese freight traffic in Hungary]. NAVIGÁTORVILÁG. January 27. Retrieved from: https://www.kozlekedesvilag.hu/cikk/nv/kinai-aruforgalom-magyarorszagi-vamkezelesenek-felgyorsitasa/ (accessed on: May 02, 2021) [in Hungarian].

2. Bakai, K.P. (2016). A 42-es eljárásban történő adómentes termékbehozatallal kapcsolatos visszaélések elleni nemzetközi fellépés tapasztalatai [Experiences from the international counter-action against the tax-free goods' import-related impositions under procedure type 42]. Válogatott tanulmányok a Vám-és Pénzügyöri Tanszék fennállásának 25. évfordulója alkalmából - Selected studies celebrating the 25th anniversary of 
the Department of Customs and Finance Guad / Á. Zsámbokiné Ficskovszky (ed.). Budapest, pp. 12-33 [in Hungarian].

3. Barton, T.B. et al. (2007). Expanded borders, integrated controls. Achieving national prosperity and protection through integrated border management. Border Management in the New Century. Emerging Trends and Best Practices / T.B. Barton (ed.). New York: IBM Global Services, Somers, pp. 3-18 [in English].

4. Chen, Rong (2013). A Critical Analysis of the U.S. "Pivot" toward the Asia-Pacific: How Realistic is Neo-realism? Connections, vol. 12, no. 3, pp. 39-62 [in English].

5. Csaba, Z. (2012a). Határellenőrzés kockázati értékelése: Határátkelőhelyek kockázati profilja [Risk assessment of border control. Risk profiles of border stations]. Magyar Rendészet, no. 1, pp. 69-77 [in Hungarian].

6. Csaba, Z. (2012b). Kritikus infrastruktúra - gazdasági biztonság [Critical infrastructure - economic security]. Hadtudomány, no. 3-4, pp. 171-175 [in Hungarian].

7. Csaba, Z. (2013). A tengeri konténeres szállítás biztonsága [The safety of maritime container transport]. Fejezetek a kritikus infrastruktúra védelemböl: kiemelten a közlekedési alrendszer - Excerpts from the protection of critical infrastructure: particularly the road network sub-system / F. Horvatth (ed.). Budapest: Magyar Hadtudományi Társaság, pp. 133-166 [in Hungarian].

8. Csutak, Z. (2019). Strategic repositioning of the United States. Hungarian Defence Review, no. 1-2, pp. 140 [in English].

9. Csutak, Z. (2020). A 21. század hidegháborúja: USA vs. Kína [The Cold War of the 21 st century: USA v. China]. Ludovika Kiadó, Frontier blog. Budapest [in Hungarian].

10. Engelberth, I., Sági, J. (2017). Az Új selyemút kezdeményezés szerepe, céljai [Goals and roles of the new Silk Road]. Külügyi Szemle. Külügyi és Külgazdasági Intézet-Hungarain Journal of Foreign Affairs, XVI. Évfolyam, 3. szám. pp. 89. Retrieved from: https://kki.hu/assets/upload/05_Engelberth-Sagi.pdf(accessed on: May 22, 2021) [in Hungarian].

11. EPSC (2016). Engaging China at a Time of Transition - Capitalising on a New Era of Chinese Global Investment and Foreign Policy Initiatives. Issue 16.15 Retrieved from: https://ec.europa.eu/epsc/publications/ strategic-notes/engaging-china-time-transition_en\#h-2 (accessed on: April 10, 2021) [in English].

12. Erdős, Á. (2018). A gyermekek drogfogyasztásának változásai - a Gyermekjogi Egyezmény végrehajtásáról szóló civil jelentés tükrében [Changes in children's drug-consumption - on reflection of the civilian report on the implementation of the Convention on the Rights of the Child]. Fundamentum, no. 1, pp. 87 [in Hungarian].

13. Erdős, Á. (2021). Tiltott pszichoaktív szerek csempészete a hazai légiforgalomban [Smuggling of illicit psychoactive substances in international air traffic in Hungary]. Interdiszciplináris Drogszemle, no. 2, pp. 8 [in Hungarian].

14. Eszterhai, V. (2017). A “16+1 együttmüködés" bemutatása [Introduction of the $16+1$ cooperation]. Retrieved from: http://www.geopolitika.hu/hu/2017/11/01/a-16-1-egyuttmukodes-bemutatasa/\#_edn23 (accessed on: April 15, 2021) [in Hungarian].

15. Europol (2017a). European Union Serious Organised Crime Threat Assessment 2017. Crime in the age of technology (public version). The Hague, pp. 42, 46 [in English].

16. Europol (2017b). Europol and the People's Republic of China join forces to fight transnational crime: press release (19 April 2017). Retrieved from: https://www.europol.europa.eu/newsroom/news/ europol-and-people's-republic-of-china-join-forces-to-fight-transnational-crime (accessed on: April 03, 2021) [in English].

17. Goreczky, P. (2017). Kína kapcsolata Közép- és Kelet-Európával: a “16+1” együttmüködés eddigi mérlege [The nexus of China with Central and Eastern Europe: the balance of the 16+1 cooperation]. Külügyi és Külgazdasági Intézet, T-2017/9, pp. 6-9 [in Hungarian].

18. Horváth, J., Kovács, G. (2014). A rendészeti szervezetek vezetés és szervezéselmélete [Leadership and administrative theory of the law enforcement organizations]. Nemzeti Közszolgálati Egyetem. Budapest [in Hungarian].

19. Hszü, Kang (2019). Az Övezet és Út kezdeményezés és a magyar fejlesztési stratégia közti szinergiák: helyzetkép és kilátások [The synergies between the Road and Belt Initiative and the Hungarian development strategies: present state and perspectives]. Magyarország és Kína: 70 éves kapcsolat a változó világban Hungary and China: 70-year old relationship in a changing world / P. Goreczky (ed.). Budapest: Külügyi és Külgazdasági Intézet, pp. 60 [in Hungarian].

20. Kocsis, B.J., Komjáthy, D., Péti, M. (2017). Kína Új Selyemút kezdeményezésének bemutatása és nemzetközi értelmezései [Introducing the new Silk Road Initiative of China and its international interpretations]. Retrieved from: http://unipub.lib.uni-corvinus.hu/3342/1/selyemut_gfoldrajz_kocsisj_komjathyd_petim2.pdf [in Hungarian]. 
21. Kovács, G. (2016). A Migráció bűnügyi hatásai a magyar határrendészet kockázatelemzési rendszerére [Criminal impact of migration on the risk analysis system of the Hungarian border guard]. A migráció bünügyi hatásai -Criminal effects of migration / Z. Hautzinger (ed.). Budapest: Magyar Rendészettudományi Társaság Migrációs Tagozat, pp. 141-150 [in Hungarian].

22. KSH (2014). Magyar-kínai gazdasági kapcsolatok [Chinese-Hungarian trade relations]. Statisztikai Tükör, no. 25, pp. 1. Retrieved from: https://www.ksh.hu/docs/hun/xftp/stattukor/magyarkinaigkapcs.pdf (accessed on April 18, 2021) [in Hungarian].

23. KSH (2020). Helyzetkép a külkereskedelemröl, 2019 [Current state of affairs in foreign trade, 2019]. Központi Statisztikai Hivatal. Budapest, pp. 23. Retrieved from: http://www.ksh.hu/docs/hun/xftp/idoszaki/ kulker/2019/index.html (accessed on: February 5, 2021) [in Hungarian].

24. KSH (2021). A külkereskedelmi termékforgalom forintban, országok szerint [Foreign trade product turnover in HUF, by country]. Retrieved from: http://www.ksh.hu/docs/hun/xstadat/xstadat_eves/i_qkt009c. html?down=1751 (accessed on: March 15, 2021) [in Hungarian].

25. Magasvári, A. (2015). Adó- és vámhatóságok szervezeti integrációja - bilaterális összehasonlítás, avagy egy tanulmányút tapasztalatai [Organizational integration of tax and customs authorities - bilateral comparison or the experiences of a field study-trip]. Az adó- és vámszolgálatok aktuális kihívásai - Current challenges of the tax and customs services / A. Zsámbokiné Ficskovszky, A. Szabó (eds.). Budapest: Magyar Rendészettudományi Társaság, pp. 165-176 [in Hungarian].

26. Magasvári, A. (2018). A Nemzeti Adó- és Vámhivatal szerepe, szervezete, feladatai, személyi állománya [Role, organzation, tasks and personnel of the National Tax and Customs Administration]. Integrált pénzügyöri ismeretek I. Kezdö pénzügyőrök kézikönyve - Integrated know-how of financial inspectors I. Manual of beginner finance inspectors / A. Erdős (ed.). Budapest: MRTT Vám- és Pénzügyőri Tagozata, pp. 25-43 [in Hungarian].

27. Magasvári, A. (2018). Az emberi tényező szerepe a változás sikerében - egy integráció margójára [The role of human factor in the success of change - on the margin of an integration]. Tavaszi Szél $2018=$ Spring Wind 2018: Tanulmánykötet / G. Keresztes, C. Szabó (eds.). Budapest: Doktoranduszok Országos Szövetsége, pp. 507-516 [in Hungarian].

28. Majoros, P. (2008). Az átalakuló magyar külgazdasági stratégia új elemei [New elements of the transforming Hungarian foreign trade policy]. EU Working Papers, 11. évfolyam, no. 1/2008/1, pp. 11. Retrieved from: https://epa.oszk.hu/00000/00026/00038/pdf/ (accessed on: April 10, 2021) [in Hungarian].

29. Mátyás, S. (2016). Turizmus és viktimizáció [Tourism and victimization]. I. Turizmus és biztonság tudományos konferencia konferencia-kötete - Compilation of conference lectures of the First scientific conference on Tourism and Security / K. Német (ed.). Nagykanizsa: Pannon Egyetem, pp. 47-59 [in Hungarian].

30. MTI (2020). A Huawei új kutatás-fejlesztési központot épít Budapesten [Huawei is building a new research \& development center in Budapest]. Retrieved from: https://kormany.hu/hirek/a-huawei-uj-kutatasfejlesztesi-kozpontot-epit-budapesten (accessed on: May 22, 2021) [in Hungarian].

31. NAV (2020a). NAV Évkönyv 2019. Tények, információk a Nemzeti Adó- és Vámhivatal szervezetéről és 2019-es tevékenységéről [NAV Yearbook 2019. Facts, information about the activity of the National Tax and Customs Administration in 2019]. Budapest, p. 49. Retrieved from: https://nav.gov.hu/nav/kiadvanyok (accessed on: May 2, 2021) [in Hungarian].

32. NAV (2020b). Bulletin - NAV Dél-budapesti Adó- és Vámigazgatósága [Bulletin of the South Budapest Directorate of National Tax and Customs Administration, 2019]. Budapest, pp. 10. Retrieved from: https://nav.gov.hu/nav/igazgatosagok/del_budapest/helyi_hirek_barm/bulletin2019. html?query=NAV+D\%C3\%A91-budapesti $+\mathrm{Ad} \% \mathrm{C} 3 \% \overline{\mathrm{B}} 3-+\% \mathrm{C} 3 \% \mathrm{~A} 9 \mathrm{~s}+\mathrm{V} \% \mathrm{C} 3 \% \mathrm{~A} 1$ migazagt $\% \mathrm{C} 3 \% \mathrm{~B} 3 \mathrm{~s} \% \mathrm{C} 3$ $\% A 1$ ga +2019 (accessed on: May 2, 2021) [in Hungarian].

33. NAV (2021). Megszünik a 22 eurós áfamentességi értékhatár [Annuling the Union 22 Euro value threshold]. Retrieved from: https://www.nav.gov.hu/nav/sajtoszoba/hirek/Megszunik_a_22_euros_20210408. html (accessed on: April 24, 2021) [in Hungarian].

34. P. Szabó, S. (2011). Magyar-kínai gazdasági kapcsolatok és a Nemzeti Adó- és Vámhivatal [The National Tax and Customs Administration and the Hungarian- Chinese relations]. Közszolgálat. Közigazgatási Magazin, no. 1(3), pp. 49-50 [in Hungarian].

35. P. Szabó, S. (2020). A Kínai Népköztársaság "kétvágányos" külpolitikája [The "double-track" foreign policy of the Republic of China]. Lehetöségek és kihívások a magyar-kínai kapcsolatok területén. I. kötet Politikai kapcsolatok - Opportunities and challenges in the field of Sino-Hungarian relations / S. P. Szabó, P.C. Horváthné Varga (eds.). Budapest: Dialóg Campus, pp. 23 [in Hungarian].

36. Rácz, G. (2020). A Kínai Népköztársaság és az EU kapcsolatai és kapcsolatépítési stratégiái [The Chinese-EU nexus and relation-building strategies]. Lehetöségek és kihívások a magyar-kínai kapcsolatok 
területén. I. kötet Politikai kapcsolatok - Opportunities and challenges in the field of Sino-Hungarian relations / S. P. Szabó, P.C. Horváthné Varga (eds.). Budapest: Dialóg Campus, pp. 151 [in Hungarian].

37. Róma, Á. (2018).V4-Kína kapcsolatok-Bilaterális kereskedelem \& befektetés [V4-Chinese relations - Bilateral trade \& investment (infographic)]. Retrieved from: http://www.geopolitika.hu/hu/2018/10/02/v4kina-kapcsolatok-bilateralis-kereskedelem-befektetes/ (accessed on: April 18, 2021) [in Hungarian].

38. Kína Online (2017). Az Egy övezet, egy út elmúlt egy éve [The past one year of the One Zone, One Road initiative]. Retrieved from: https://www.kinaon.com/Kiemelt-hirek/Az-Egy-Ovezet-Egy-Ut-elmult-egyeve (accessed on: March 08, 2021) [in Hungarian].

39. Suba, L. (2015). A vámhatóság interoperabilitása - és annak kommunikációja (A 2004-es EUcsatlakozás kihívásai) [Customs interoperability - and its communication (Challenges of 2004 EU accession)]. Hadtudományi Szemle, no. 4, pp. 306-315 [in Hungarian].

40. Suba, L., Szendi, A. (2018). Az uniós vámjog vázlata [Outline of the European customs code]. Budapest: Dialóg Campus Kiadó, p. 107 [in Hungarian].

41. Szabó, A. (2012). A rendőrségi együttmüködés jogi alapjai és intézményei [Legal fundaments and the institutions of policing cooperation]. Tavaszi Szél 2012 konferenciakötet - Spring Wind Conference Compilation of studies 2012 / P. Fülöp (ed.). Budapest: Hungarian Federation of Doctoral Students, pp. 702709 [in Hungarian].

42. Szabó, A. (2016). Egy új "státusú" központi hivatal rendvédelmi feladatai [Law enforcement duties of a new "status" central authority]. A toll sokszor erösebb, mint a kard - Pen is often stronger than sword / J. Deák, G. Gaál, J. Sallai (eds.). Budapest: Nemzeti Közszolgálati Egyetem Rendészettudományi Kar, pp. 200-210 [in Hungarian].

43. Szunomár, Á. (2015). Blowing from the East. International Issues \& Slovak Foreign Policy Affairs, vol. XXIV, no. 3/2015, pp. 64. Retrieved from: http://real.mtak.hu/34185/1/Szunomar_Blowing_from... SFPA_u.pdf (accessed on: April 18, 2021) [in English].

44. Cooperation between China and Central and Eastern European Countries (2015). The Belgrade Guidelines for Cooperation between China and Central and Eastern European Countries. Retrieved from: http://www.china-ceec.org/eng/ldrhw_1/2014bergld/hdxw/t1410498.htm (accessed on: April 26, 2021) [in English].

\section{Source:}

URL1 - http://www.kormany.hu/hu/kulgazdasagi-es-kulugyminiszterium/hirek/regionalis-kozpontot-nyita-bank-of-china-magyarorszagon (accessed on: April 15, 2021).

URL2 - Potential Chinese investments in Rijeka, Trieste may threaten Slovenia's Koper port. PortSEurope. 2021. April 17. URL: https://www.portseurope.com/potential-chinese-investments-in-rijeka-trieste-maythreaten-slovenias-koper-port/ (accessed on: April 15, 2021).

URL3 - http://2015-2019.kormany.hu/hu/kulgazdasagi-es-kulugyminiszterium/hirek/felertekelodik-akeleti-nyitas-strategia (accessed on: April 15, 2021).

URL4 - https://www.kormany.hu/hu/nemzetgazdasagi-miniszterium/hirek/a-budapest-belgradvasutfejlesztesrol-targyalt-varga-mihaly-kinaban (accessed on: April 15, 2021).

URL5 - https://www.vg.hu/vallalatok/kozlekedes/kiemelt-statuszt-kapott-a-budapest-belgradvasut-3596041/ (accessed on: April 18, 2021).

URL6 - http://www.rne.eu/rail-freight-corridors/rail-freight-corridors-general-information/ (accessed on: April 10, 2021).

URL7-Cigarette Smuggling Still Booming. OCCRP Organized Crime and Corruption Reporting Project. URL: https://www.reportingproject.net/underground/index.php?option=com content\&view=article\&id=5\&Itemid=1 (accessed on: April 10, 2021).

URL8 - https://www.consilium.europa.eu/en/council-eu/preparatory-bodies/customs-cooperationworking-party/ (accessed on: April 10, 2021).

URL9 - https://ec.europa.eu/anti-fraud/policy/joint-customs-operations/operation-snake-eu-and-chinesecustoms-join-forces-target_en (accessed on: April 10, 2021). 


\title{
УГОРЩИНА ТА КИТАЙ: ВИКЛИКИ Й РИЗИКИ, 3 ЯКИМИ СТИКАЮТЬСЯ ПОДАТКОВІ ТА МИТНІ ОРГАНИ
}

\author{
Андреа ШАБО, \\ завідувач кафедри митної та фінансової служб \\ факультету правоохоронної діяльності \\ Національного університету державної служби Угорщиини, \\ доиент \\ szabo.andrea@uni-nke.hu \\ orcid.org/0000-0002-8224-4089
}

\section{Давід ТАКАЧ,}

співробітник відділу акиизного податку, перший лейтенант, Національна податкова та митна адміністрачія Угорщини,

Центральне управління кримінальних розслідувань, аспірант

takacs.david_1@nav.gov.hu

\section{Крістоф Петер БАКАІ,}

генеральний директор митної служби

Національної податкової та митної адміністрачії,

здобувач

bakai.kristof@nav.gov.hu

orcid.org/0000-0002-1809-5533

Метою дослідження є огляд поточного стану китайсько-угорської торгової політики, а беручи до уваги той факт, що Угорщина є державою - членом Європейського Союзу, угорська податкова служба, імовірно, зіткнеться з певними професійними та кількісними викликами.

Дослідження узагальнюе висновки, доступні у вітчизняній $і$ міжнародній академічній літературі, та занепокоєння щзодо питань ініціативи «Один пояс, один шлях» та ії конкретних иілей, залучення Угорщини як одного з головних залізничних шлюзів контейнерних вантажних перевезень. Крім того, також проаналізовано дані Центрального статистичного управління Угорщиини та Національної податкової та митної адміністрації.

Метою «східного відкриття» Угорщини є пошук нових джерел сировини та ринків збуту для угорських корпораиій, оскільки економіка на захід від країни характеризується високими зарплатами та витратами на транспортування. Немає сумніву, що у ХХІ столітті фокус світової економіки змістився на Схід, а Азія стала континентом із найбільшим ринком покупців у світі. 3 огляду на це варто зазначити, що «східне відкриттяя не зосереджується виключно на Китайській Народній Республіиі, а включає також усі основні регіони (Majoros, 2008: 11) - від Кавказького регіону через Балкани до арабського світу.

Валовий обсяг двосторонньої торгівлі між Китаєм та Угорщиною, згідно з показниками Центрального статистичного управління Угорщини, становив 382 млрд форинтів у 2001 роиі та 1284 млрд форинтів у 2010 роиі, тоді як після чотирирічного падіння показник зріс до 1700 млрд форинтів у 2018 роиі (без урахування даних для Гонконгу та Тайваню).

Таке зростання свідчить про трансформащію системи завдань нащіональної податкової служби, а також про необхідність вирішення кількості нових типів професійних процедур, пов'язаних з управлінням персоналом та митним управлінням, що постійно зростає. Можна помітити, що національна митна служба робить усе можливе, щоб відповідати європейським очікуванням, зокрема: зменшує тривалість митних процедур, здійснюе так звану політику справедливої иіни, иентралізує митні пункти, загалом сприяє здійсненню унітарних і швидких митних процедур.

Зметою визнання та боротьбиз ризиками служба обмінюється протоколами тісної співпраиі із Всесвітньою митною організаиією, а також з установами Європейського Союзу, наприклад ОЛАФ та Європолом.

Ключові слова: міжнародна торгівля, східне відкриття, Новий шовковий шлях, митна служба, рішення, митниця. 